\title{
Prospect of beneficial microorganisms applied in potato cultivation for sustainable agriculture
}

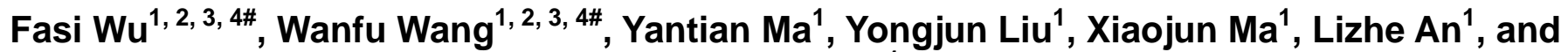 \\ Huyuan Feng ${ }^{1 *}$ \\ ${ }^{1}$ School of Life Sciences, Lanzhou University, Lanzhou, 730000, PR, China. \\ ${ }^{2}$ National Research Center for Conservation of Ancient Wall Paintings and Earthen Architecture Sites, Dunhuang, \\ Gansu, 736200, PR, China. \\ ${ }^{3}$ Key Scientific Research Base of Conservation for Ancient Mural, State Administration for Cultural Heritage, Dunhuang, \\ Gansu 736200, PR, China. \\ ${ }^{4}$ Conservation Institute of Dunhuang Academy, Dunhuang, Gansu, 736200, PR, China.
}

Accepted 26 April, 2013

\begin{abstract}
Potato (Solanum tuberosum L.) is a widely planted crop. The primary obstacles for potato production are the high demands of fertilizers and the occurrence of widespread diseases. Traditional intensively managed agroecosystems depend on fertilizers and biocides, which could induce soil degradation and environmental problems. This review emphasizes the effects of inoculating crops with plant growthpromoting bacteria, endophytes, especially arbuscular mycorrhizal fungi (AMF), as well as the potential application of these microbes in the establishment of a sustainable potatoes cultivation system. We concluded that it is worth to isolate the most efficient microbial strains during the process of microbial diversity investigations. And it is also worth to apply flavonoids and other stimulators to promoter beneficial microbes growth since emerging evidence implies that these compounds can stimulate native mycorrhizal activity and subsequent potato yield. In summary, more practical application of biofertilizers and bio-control methods should be encouraged to facilitate potato production.
\end{abstract}

Key words: Arbuscular mycorrhizal fungi, beneficial microbes, disease resistance, potato production, sustainable agriculture.

\section{INTRODUCTION}

Potato is a global crop planted in a wider range of altitude, latitude, and climatic conditions. No other crop can match the potato in its production of food energy and food value per unit area (Davies et al., 2005b). Nutrition analysis showed that potato is a healthy food in terms of vitamins, minerals, proteins, antioxidants, essential amino acids and carbohydrates (Andre et al., 2007).
However, there are many problems surrounding potato cultivation. One problem is that potato plant has one of the heaviest production demands for fertilizer inputs of all vegetable crops. Normal fertilizer application is around $1000 \mathrm{~kg} \mathrm{ha}^{-1} 10 \mathrm{~N}-3 \mathrm{P}_{2} \mathrm{O}_{5}-10 \mathrm{~K}_{2} \mathrm{O}$. $\mathrm{N}$ requirements are as high as $336 \mathrm{~kg} \mathrm{ha}^{-1}$ in traditional production system for an expected yield of $5000 \mathrm{~kg} \mathrm{ha}^{-1}$ (Davies et al., 2005b; Lang 
et al., 1999). The increasing demands for potato in the world are accompanied with the higher utilization of chemical fertilizers. Another problem is the occurrence of prevalent diseases. For example, late blight, caused by Phytophthora infestans, is commonly thought to be the major threat to potato production (Finckh et al., 2006; Struik, 2010). Therefore, quantities of pesticides and fungicides are needed in potato planting process.

Current agriculture are facing increased cost of synthetic fertilizer, (agro) ecosystems desiccation caused by extensive use of water in crop production (Whitley and Davenport, 2003) and subsequent reduction in water supplies for irrigation, heightening publication about the environmental and healthy impact of biocide overuse (Lotter, 2003), and the nitrate leaching from overuse of fertilizers, therefore, a new program must be developed to address these challenges. Thereafter, applying beneficial microbial inoculants are emerging as a promising alternative for maintaining a sustainable agriculture system.

Evidence shows that maintenance of sustainable soil fertility depends greatly on the ability to harness the benefits of plant-growth-promoting bacteria (PGPB) such as $\mathrm{N}$-fixing, P-solubilizing bacteria (PSB), mycorrhizal helper bacteria (MHB), endophytes, and arbuscular mycorrhizal fungi (AMF) (Barea et al., 2005; Smith and Read, 2008). In particular, the association of AMF with most of the terrestrial plants is geographically ubiquitous and occurs over a broad ecological range. A majority of the agricultural and horticultural crops and forest trees have been reported to be mycorrhizal (Reddy et al., 2005). The consensus is that soil microbial activities are major factors that determine the availability of nutrients to plants, consequently they have significant influence on plant health and productivity (Jeffries et al., 2003). Indigenous or introduced beneficial microbes could benefit crops, such as wheat (Wu et al., 2011), corn (Deguchi et al., 2007), vegetable crops (Han et al., 2006), cassava (Straker et al., 2010), and potato plants (Bhattarai and Mishra, 1984; Vosátka and Gryndler, 2000).

In recent years, studies have focused mainly on the effects of microbial inoculation on potato, including yield enhancement (Davies et al., 2005a; Yao et al., 2002), diseases biocontrol (Whipps, 2004), and quality amelioration (Duffy and Cassells, 2000).

In this review, we discuss the functions of beneficial microorganisms (especially PGPB and AMF) on plant growth and their inoculation effects on potato production. We also review the significance and potential of the combination of AMF with other appropriate beneficial organisms. We summarize the advances and problems in production of lower cost, high efficiency inoculants, and analyze the considerations in the practical application of beneficial microorganisms. From the agricultural and ecological viewpoints, we aim to improve potato yield and quality while maintaining soil quality.

\section{DIVERSE FUNCTIONS OF BENEFICIAL MICROORGANISMS}

\section{P uptake}

Compared with the other major nutrients, phosphate $(P)$ is the least mobile mineral to plants in most soil conditions, because it can form insoluble compounds with most of the dominant free cations in soils, the efficiency of the plant uptake might be as low as $20 \%$, and it is frequently the primary limiting factor for plant growth (Sanders and Tinker, 1971). However, the rhizosphere microorganisms can benefit their host principally by increasing the uptake of relatively immobile $\mathrm{P}$ (Smith and Read, 2008). More attention has been paid to microbial improvement for $\mathrm{P}$ nutrient with regard to agricultural applications lately.

The primary effect of PGPB and AMF establishment is to improve $P$ uptake by plants due to the role of PSB (Dadhich et al., 2006; Wani et al., 2007) and the establishment of external mycelium of AMF, which act as a bridge between roots and the surrounding soil microhabitats (Barea et al., 2005). The fungal mycelium transports $\mathrm{P}$ ions from the soil solution beyond the Pdepletion zone to the plant roots (Smith and Read, 2008). Moreover, it is widely recognized that these microbes can perform crucial functions in biogeochemical cycling in both agricultural and natural ecosystems (Jeffries et al., 2003). Therefore, the potential of these microbes to improve the way $\mathrm{P}$ additions are used in agriculture is of great interest.

In potato, adequate $\mathrm{P}$ nutrition is critical for tuber development and high photosynthetic rate maintenance during tuber bulking. $P$ nutrition is also linked to the assimilation of other mineral nutrients and improvement of protein contents (Mishra et al., 2007). The potato has an inherently low root density and restricted ability to uptake fertilizer $P, P$ deficiency is usually a limiting factor to yield in commercial potato production (Mackay et al., 1988). Large amounts of chemical $P$ fertilizers had to be added annually to cultivated soil. Unfortunately, $P$ is increasingly costly to extract and $\mathrm{P}$ supplies are predicted to be exhausted before the end of this century.

A pot study confirmed enhanced $P$ uptake by roots at various levels of abiotic $P$ supplies by the inoculation of AMF to potato (McArthur and Knowles, 1993). The alleviation of $P$ deficiency in no- $P$ and low- $P$ plants by these microbes stimulated the uptake of $\mathrm{N}, \mathrm{K}, \mathrm{Mg}$, Fe, and $\mathrm{Zn}$ simultaneously. Even under a higher $\mathrm{P}$ supply regime in which no growth benefit was obtained, no detrimental effect was observed (McArthur and Knowles, 1993). Furthermore, potato yields are foremost limited by nutrient availability in spring and early summer (Finckh et al., 2006), while these microbes may benefit the yield of potato by enhancing $P$ accumulation during early- to midseason growth periods (McArthur and Knowles, 1993).

The first mycorrhiza-specific plant $P$ transporter gene 
StPT3 was identified from potato (Rausch et al., 2001), and it has been shown that this gene is highly expressed in root cells harboring various mycorrhizal structures (Karandashov et al., 2004). Different AMF taxa contain different $\mathrm{P}$-transporter genes and genetic variations in $\mathrm{P}$ acquisition pathways could potentially explain why different AMF supply inconsistent amounts of $P$ to plants (Harrison, 2005).

P-solubilizing ability of PSB is also linked to genotype (Gyaneshwar et al., 2002). Therefore, understanding the genetic basis of $P$ solubilization would help in transforming more rhizosphere-competent bacteria into PSB in the future. These microbes are usually considered to play vital roles and it is assumed that they can be used as biofertilizer to reduce or eliminate chemical fertilizers inputs (Asok and Jisha, 2006; Shah et al., 2007).

\section{Yield enhancement}

Soil microbes are important regulators of plant productivity, especially in nutrient poor ecosystems. The presence of AMF can alter the plant community structure and productivity (Klironomos et al., 2000; Niemira et al., 1995). The AMF symbionts could stimulate leaf growth and expansion (McArthur and Knowles 1993), increase shoot fresh weight, root dry weight and the number of tubers produced per potato plant (Graham et al., 1976; Yao et al., 2002). AMF inoculants promoted the number of minitubers per plant and the weight per minituber (Vosátka and Gryndler, 2000). Thus the AMF inoculation is potential useful to post-vitro transplanted plants in microtuber seed production systems. However, one consideration is that appropriate microbe isolation should be selected for a particular host genotype. When the micro plants of potato were inoculated with three commercial AMF inoculants in the glasshouse (Duffy and Cassells, 2000), the yield quality of potato micro plants mainly depended on the mycorrhizal isolate and host plant genotype.

In field studies, inoculation with commercial inoculants containing AMF (Glomus intraradices) resulted in higher yields and larger tubers than treatments using conventional chemical fertilizers over two growing seasons (Douds et al., 2007). Meanwhile, yield promotion by N-fixing bacteria and PSB were also reported in other crops including wheat (Khalid et al., 2004), maize (Hameeda et al., 2006), chickpea (Wani et al., 2007), and soybean (Dadhich et al., 2006).

The factors that determine the tuber yield and tuber size distribution in potato are more complex than previously thought. The AMF enhance potato tuber production partly due to the increased nutrient uptake, particularly $P$ uptake (McArthur and Knowles, 1993), and enhanced disease resistance as discussed in next section (Niemira et al., 1996).

\section{Biocontrol}

Potatoes are susceptible to several diseases that cause yield reduction. Currently, late blight (caused by Phytophthora infestans) and black scurf (caused by Rhizactonia solani) are still the central diseases in the cultivation of potato (Finckh et al., 2006; Struik, 2010). There is still no effective fungicide available to control late blight. In addition, common scab (caused by Streptomyces scabies), silver scurf (caused by Helminthosporium solani) and sometimes soft rot (caused by Erwinia carotovora var. atroseptica) may cause serious problems (Finckh et al., 2006). Rhizoctonia disease of potato is another problem that occurs throughout the world. Rhizoctonia solani is an important soilborne plant pathogen that affects potato growth (Vosátka and Gryndler, 1999). R. solani-infected plantlets may develop crown rot, root rot, or stem canker, which often leads to wilting and even plant death. To control these pathogens, significant use of pesticide and fungicide is required.

AMF and PSB play a role in the suppression of crop pests and diseases (Asok and Jisha, 2006)), including pathogenic nematodes ( $\mathrm{Hol}$ and Cook, 2005), herbivores (Gange et al., 2002) and particularly soil-borne fungal diseases (Borowicz, 2001). Some potato-associated endophytes were found to antagonize fungal or bacterial pathogens by increasing the production of active compounds including enzymes, antibiotics, siderophores, and the plant hormone indole-1,3-acetic acid (Sessitsch et al., 2004). Attention has been concentrated on the biocontrol of plant pathogens, a potential substitute for chemical pesticides (Yao et al., 2002). The biocontrol amendments Rhizoctonia solani isolate Rhs1A1 and Trichoderma virens, increased microbial activity and bacterial populations in organic and conventional potato production systems (Bernard et al., 2012). AMF and antagonistic bacteria utilization, through inoculation of crops or stimulation of naturally occurring populations, could be a promising approach to control the development of potato diseases. Niemira et al. (1996) indicated that the fungus Glomus intraradices can suppress the development of potato dry rot, a post-harvest disease caused by the fungus Fusarium sambucinum, but the efficiency sometimes relied on species specificity of inoculants (Niemira et al., 1996). But when AMF used as the biocontrol agents of potato in greenhouse and field trials, it can reduce soilborne disease stem canker and black scurf by 17-28\% (Larkin, 2008). One interesting phenomena is that highly diseases resistant potato cultivars showed an earlier establishment and more rapid development of AMF colonization than highly susceptible cultivars (Bhattarai and Mishra, 1984; Yao et al., 2002), however, the mechanism is unclear.

The establishment of AMF in plant roots can reduce the damage caused by soil-borne plant pathogens, with an enhancement of plant resistance/tolerance in mycorrhizal plants (Harrier and Watson, 2004). In nematode control 
studies, inoculation of potato plants with AMF delayed nematode hatching (Ryan et al., 2000). Root leachates from AMF-inoculated potato plants have multiple effects on the production of nematode hatching factors (Deliopoulos et al., 2007). Mechanisms, such as enhanced competition and changed living environment have been used to account for this resistance/tolerance effect (Elmer, 2002). It can be simply attributed to increased root systems of mycorrhized plants or competition between AMF and pathogens for resources and spatial niches (Maherali and Klironomos, 2007) Another reason for plant resistance is the changes of rhizosphere microbial communities. The shifts in microbial community structure and the resulting microbial equilibria could influence the growth and health of plants (Borowicz, 2001). This may indirectly lead to the activation of plant defense mechanisms, including the development of systemic resistance which have been induced by AMF (Whipps, 2004), AMF root colonization may alter the phenolic metabolism of roots, to hinder ethylene production and the root's ability to provoke a defense response (McArthur and Knowles, 1992). However, the mechanisms and their impact on biological control still need further research.

Microbes such as AMFs were considered promising biocontrol agents to manage pathogens and potato nematode. To some extent, biocontrol effects of microbes depend on the AMF species, the substrate, and the host plant involved (Borowicz, 2001; Whipps, 2004). More studies are necessary to determine their potential application as a part of a wider biocontrol strategy.

\section{Other available functions}

Several studies, using mesocosms or field trials, have shown that the presence or the diversity of the AMF can have strong influence on plant community composition (van der Heijden et al., 1998), growth and competitive ability of plants (Bever et al., 2001), and hormonal balance (Gadkar et al., 2001). It also has been shown that AMF colonization can help plants to cope with drought and salinity stresses (Augé, 2001).

The use of microbial community inoculants in the rhizosphere of target indigenous plants is a successful biotechnological tool for the recovery of degraded ecosystems. This can be used as an initial step in the restoration of a self-sustaining ecosystem (Barea et al., 2005). A well-aggregated soil structure wrapped by mycorrhizal hypha improved soil-plant water relations, soil aeration, root penetrability and soil organic matter accumulation, all contribute to soil quality and drought tolerance (Rillig and Mummey, 2006). More research should be focused on the functional diversity of these microbes, so as to integrate their use in sustainable agriculture.

\section{DEVELOPMENT OF PRACTICAL APPLICATIONS}

\section{Strain selection}

PSB, KSB (K-solubilizing bacteria), endophytes, and AMF symbiosis play pivotal roles in plant growth, health, and soil quality: these symbionts are therefore important cornerstones in sustainable agricultural systems.

Screening of the appropriate microbes seems to be a useful way for practical application (Khalid et al., 2004; Klironomos, 2003). The evidence show that plants may be associated with AMF which may benefit them the most (van der Heijden et al., 1998), effects of AMF varies with the species in soybean (Dadhich et al., 2006), maize (Wu et al., 2005), and potato (Duffy and Cassells, 2000), in terms of plant growth, yield, mineral nutrition, and responses against pathogen agents (Harrier and Watson, 2004). The response differences of crops to the symbionts were related to the selectivity of host plant and their compatibility. Composition and diversity of potatoassociated antagonists were mainly specific for each microenvironment (Berg et al., 2005). Recently, van Overbeek and van Elsas (2008) investigated the effects of genotype, plant growth and experimental factors (soil and year) on potato-associated bacterial communities, which founded that plant growth stage overwhelmed any effect of plant genotype on the bacterial communities associated with potato (Van Overbeek and Van Elsas, 2008). Such differences justify the need to ensure the best combinations of host/microbial/substrate/inoculants type to make a better use of inoculation in crop improvement and disease control (Davies et al., 2005b). Thus, local isolates are recommended for biotechnological applications (Klironomos, 2003).

By screening effective rhizospheric soils as inoculum from 12 different plant species grown as monocultures at a field site in northern Sweden, the AMF propagules from the hosts Festuca ovina and Leucanthemum vulgare were considered to be highly effective inoculants for potato cultivation (Bharadwaj et al., 2007). The most efficient bacteria and fungi for potato growth isolated from 15 different crop plants were Penicillium sp., Pseudomonas sp., Bacillus sp., and Glomus mosseae (Asok and Jisha, 2006; Davies et al., 2005b). But G. intraradices was the most abundant fungus in potato roots (Cesaro et al., 2008). A total of 2648 potato-associated bacteria were screened by dual testing of antagonism to the soilborne pathogens Verticillium dahliae and Rhizoctonia solani, the most prominent species was Pseudomonosas putida (Berg et al., 2005). Additionally, 800 species were isolated from rhizospheres and endospheres at the flowering stage of potato plants, one of Lysobacter sp. was considered to be the best antagonists (Van Overbeek and Van Elsas, 2008). Sixteen AMF morphotypes were identified in potato under field conditions in India, and they proved that dark septate endophytes (DSE) and AMF colonization progressed synchronously 
Table 1. Interactions between AMF and rhizosphere micro-organisms.

\begin{tabular}{lll}
\hline Parameter & Interactions with AMF & Referencee \\
\hline N-fixing bacteria & Improved N-fixing and transfer & (Gadkar et al., 2001) \\
PSB & $\begin{array}{l}\text { Establishment of PSB; corporate to increase P capture, } \\
\text { cycle, and supply }\end{array}$ & (Barea et al., 2005) \\
KSB & AMF establishment and K uptake & (Wu et al., 2005) \\
$\begin{array}{l}\text { MHB (Bacillus sp. and } \\
\text { Pseudomonas sp.) }\end{array}$ & $\begin{array}{l}\text { Enhance mycorrhizal formation, mycelial growth, nutrient } \\
\text { uptake, and production of plant hormones }\end{array}$ & $\begin{array}{l}\text { (Frey-Klett et al., 2007; Mamatha et al., } \\
\text { 2002; Vosátka and Gryndler 1999) }\end{array}$ \\
\hline
\end{tabular}

with the dominance of Glomus tortuosum (Das and Kayang, 2010). Superior strain selection of beneficial microorganisms that were notably effective on particular crops is an important requirement for further practical application.

\section{Mixed-microbes inoculation}

Soil microorganisms form an important part of the interaction network known to affect plant fitness and soil quality (Barea et al., 2005). Research has demonstrated that certain co-operative microbial activities can be exploited (Johansson et al., 2004) in low-input biotechnology, to help sustainable, environmental-friendly, agrotechnological practices.

It is clear that microbial antagonist of fungal pathogens, either fungi or other microbes do not exert any antimicrobial effect against AMF (Edwards et al., 1998; Marvázquez et al., 2000), and their interactions are summarized in Table 1. This is the key to exploit the possibilities of mixed-inoculation (AMF and other PGPB) to aid plant defense against root pathogens and improve yield (Shah et al., 2007). The application of inoculants containing AMF, N-fixer, PSB and KSB resulted in increased growth of maize (Wu et al., 2005), or reduced potato diseases on tubers and increased yield (Larkin, 2008; Vosátka and Gryndler, 2000). The effects of inoculation on crop productivity in field conditions are complex phenomena: both the selection of inoculants and the field site characteristics will contribute to the successful persistence and effectiveness of the given microbes after inoculation (Farmer et al., 2007). Of course, it is difficult to rule out the contribution of indigenous strains, even those strains are less effective than the introduced ones (Koide et al., 1999; Bernard et al., 2012).

As a result, inoculants need to be carefully selected to ensure the best combination among host, microbial, substrate and inoculants type in the process of potato production (Klironomos and Hart, 2002). Mostly, the interaction studies between AMF and other microbes were based on studies in pot and greenhouse systems, little has been done in large-scale field trials.

\section{Inoculants production}

Despite the difficulty in selecting effective multifunctional microbial inoculants, new environmental-friendly, genetically-modified microbial inoculants are being produced commercially, that are used to promote plant growth and to protect plants against diseases (Tarbell and Koske, 2007). These new products are expected to result in a significant reduction in the use of biocides and chemical fertilizers (Douds et al., 2007).

However, the commercialization of PGPB and AMF products is not an easy task, the limiting factor in the use of microbial inoculants lies in their production costs. It is very costly to apply sufficient levels of inoculants to potato production systems (Davies et al., 2005b). Furthermore, the obligatory biotrophic character of AMF, demands the use of metabolically active roots for their multiplication (Smith and Read, 2008). To produce quality inoculants seems crucial for the application of these beneficial microorganisms technology in sustainable agriculture (Gianinazzi and Vosátka, 2004). How can inoculants be produced and applied in an economicallyviable, commercial-scale manner when application is necessary is a critical issue. The development of inoculant production systems is summarized in Table 2.

\section{Emerging treatments}

As for AMF development, plant exudation (that is flavornoid) has vital biological functions in regard to AMF development (Davies et al., 2005a; Requena et al., 2007). Flavonoids could stimulate indigenous AMF growth in the soil at low level (Davies et al., 2005a; Requena et al., 2007). In greenhouse studies, scientists observed that formononetin stimulated greater fungal extraradical development, net photosynthesis, stomatal conductance, increased tuber yield, and shoot develop- 
Table 2. The inoculants production process using potato plants as the host.

\begin{tabular}{llll}
\hline Mode of production & Major constituent & Products & Reference \\
\hline Lignite slurry based & Tubers, slurry, spores & Little & (Potty, 1990) \\
Peat moss based & peat moss, perlite, vermiculite, colonized roots & less & (Vosátka and Gryndler, 2000) \\
Expanded clay hydroponics & Fertilized soil, spores, colonized roots & Relative more & (Gaur and Adholeya, 2000) \\
In vitro autotrophic culture system & Micropropagated potato plantlets, AMF & A mass of & (Voets et al., 2005) \\
Field production & AM propagules, farmland & The most & (Douds et al., 2005) \\
\hline
\end{tabular}

development of potato plants (Davies et al., 2005a; Steinkellner et al., 2007). In a field study, formononetin increased potato tuber dry mass (Davies et al., 2005b). Recently, Drissner et al. (2007) reported that root secretions from mycorrhizal plants contain a lipophilic signal lysophosphatidylcholine, which are capable of inducing the $\mathrm{P}$ transporter genes StPT3 and StPT4 of potato (Drissner et al., 2007).

The potential benefits of applying flavonoid or other stimulators can promote the effectiveness of native, ecotypically adapted microbes at lower inoculum levels in field production conditions (Davies et al., 2005b; Steinkellner et al., 2007). There are excellent opportunities to manipulate indigenous microbes to enhance crop productivity, and meanwhile, to reduce agricultural chemical inputs in a cost-effective manner.

Inoculation with effective AM strains may be simpler and more effective than manipulating native communities. However, in areas of Asia and Africa, the management of or dependence upon indigenous fungi may be recommended due to the relatively high cost of inoculum (Plenchette et al., 2005). Therefore, conservation and management of local beneficial microbes seems to be very important for sustainable agro-ecosystems (Gosling et al., 2006; Koide et al., 1999) that is, minimizing mechanical tillage, reducing fallow periods, proper use of chemical stimulants and exclusion of most biocides, suitable crop rotations or intercropping.

\section{CONCLUSION AND FUTURE PROSPECTS}

In sum, beneficial microbes are involved primarily in protection against biotic and abiotic stresses, resulting often, in improved host plant growth, fitness and eco-system health. Figure 1 summarizes the effects of beneficial isolates on potato cultivation. We conclude:

1. The potato cultivation still needs large quantities of resources (water, nitrogen, energy) and chemical biocides. Microbes in sustainable crop production systems may provide an alternative to high inputs of fertilizers and chemical biocides.

2. Application of microbial inoculants must take into account the importance of microbial diversity conservation in rhizosphere, to ensure a compatible combination of host, microbial community, substrate and inoculant for realistic and effective biotechnological applications. Compound inoculation appears to be the way forward.

3. Root exudates such as flavonoids are signals of symbionts, which have more practical functions in terms of mycelium networks and output improvement. Indigenous managing seems to be another way for yield enhancement and disease resistance in sustainable agriculture ecosystem.

Currently, more attention could be paid to microbial diversity investigation, appropriate microbe selection and screening, especially commercialization of beneficial microbes. The latter one requires production of the organisms under commercial conditions while maintaining quality, stability, and efficiency of the products, compatibility with current application practices, cost, and safety testing. Conducting field practical application research is another task which seems urgent and crucial. This will lead to improved understanding of the composition and dynamics of the local beneficial microbial community, as a result, which might offer possibilities for advances in potato production.

Molecular genetic studies have been used to reveal the interaction mechanisms between microbes and the host plants. Perhaps some of the most exciting discoveries involve a combination of molecular-genetic and diversity approaches. However, it is still unclear whether functional genes (and their activities) identified by these approaches can be used to explain the effects of microbial communities on plant nutrition and disease prevention. Also, given the complexity of AMF functional variation, until we can quantify their functional variation, and classify them on a useful level, practical application of AMF cannot move forward. This is an area that is still largely unexplored. Much progress can be made through extensive collaboration of biologists in different domains.

\section{ACKNOWLEDGEMENTS}

This work was supported by the National Basic Research Program of China (2012CB026105), National Natural Foundation of China (40930533, 31260136, 31170482, 31070344), State Key Laboratory of Frozen Soil Engineering, Chinese Academy of Sciences (SKLFSE200901), $\mathrm{PhD}$ Programs Foundation of the Ministry of Education of China (20100211110021), and State Administration of 


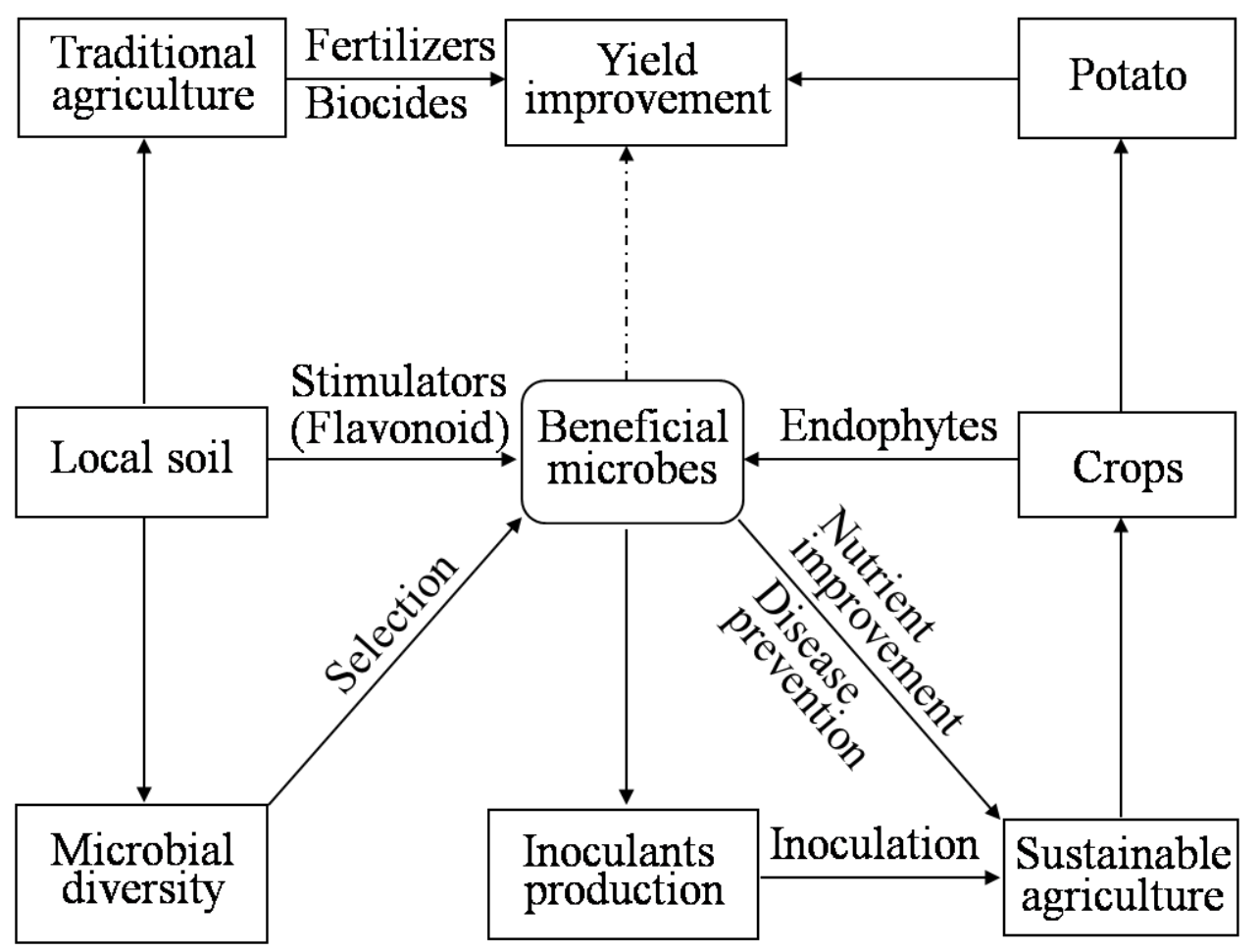

Figure 1. Simplified study process of beneficial microorganisms as a potential way for potato production.

Cultural Heritage Foundation (20110208). Critical comments and language help for this manuscript from Dr. Thorunn Helgason at University of York are thankful.

\section{REFERENCES}

Andre CM, Ghislain M, Bertin P, Oufir M, Herrera MdR, Hoffmann L, Hausman J-F, Larondelle Y, Evers D (2007). Andean potato cultivars (Solanum tuberosum L.) as a source of antioxidant and mineral micronutrients. J. Agric. Food Chem. 55: 366-378.

Asok AK, Jisha MS (2006). Role of phosphate solubilizers as bio fertilizer and anti fungal agent. Pollut. Res. 25: 515-518.

Augé RM (2001). Water relations, drought and vesicular-arbuscular mycorrhizal symbiosis. Mycorrhiza 11: 3-42.

Barea JM, Pozo MJ, Azcón R, Azcón-Aguilar C (2005). Microbial cooperation in the rhizosphere. J. Exp. Bot. 56: 1761-1778.

Berg G, Krechel A, Ditz M, Sikora RA, Ulrich A, Hallmann J (2005). Endophytic and ectophytic potato-associated bacterial communities differ in structure and antagonistic function against plant pathogenic fungi. FEMS Microbiol. Ecol. 51: 215-229.

Bernard E, Larkin RP, Tavantzis S, Susan Erich M, Alyokhin A, Sewell G, Lannan A, Gross SD (2012). Compost, rapeseed rotation, and biocontrol agents significantly impact soil microbial communities in organic and conventional potato production systems. Appl. Ecol. 52: 29-41.

Bever JD, Schultz PA, Pringle A, Morton JB (2001). Arbuscular mycorrhizal fungi: More diverse than meets the eye, and the ecological tale of why. Bioscience 51: 923-932.

Bharadwaj DP, Lundquist PO, Alström S (2007). Impact of plant species grown as monocultures on sporulation and root colonization by native arbuscular mycorrhizal fungi in potato. Appl. Soil Ecol. 35: 213-225.

Bhattarai ID, Mishra RR (1984). Study on the vesicular-arbuscular mycorrhiza of three cultivars of potato (Solanum tuberosum L.). Plant Soil 79: 299-303.
Borowicz VA (2001). Do arbuscular mycorrhizal fungi alter plantpathogen relations? Ecology 82: 3057-3068.

Cesaro P, Van Tuinen D, Copetta A, Chatagnier O, Berta G, Gianinazzi $S$, Lingua G (2008). Preferential colonization of Solanum tuberosum $\mathrm{L}$. Roots by the fungus Glomus intraradices in arable soil of a potato farming area. Appl. Environ. Microbiol. 74: 5776-5783.

Dadhich SK, Somani LL, Verma A (2006). Improved soybean yield, nutrient uptake and $P$ enrichment in soil due to co-inoculation of phosphate solubilizing bacteria and YAM fungi in a clay loam soil. Indian. J. Microbiol. 46: 405-407.

Das P, Kayang H (2010). Association of dark septate endophytes and arbuscular mycorrhizal fungi in potato under field conditions in the northeast region of India. Mycology 1: 171-178.

Davies Jr FT, Calderón CM, Huaman Z (2005a). Influence of arbuscular mycorrhizae indigenous to Peru and a flavonoid on growth, yield, and leaf elemental concentration of 'Yungay' potatoes. HortScience 40: 381-385.

Davies Jr FT, Calderón CM, Huaman Z, Gómez R (2005b). Influence of a flavonoid (formononetin) on mycorrhizal activity and potato crop productivity in the highlands of Peru. Sci. Hortic. 106: 318-329.

Deguchi S, Shimazaki Y, Uozumi S, Tawaraya K, Kawamoto H, Tanaka O (2007). White clover living mulch increases the yield of silage corn via arbuscular mycorrhizal fungus colonization. Plant Soil 291: 291299.

Deliopoulos T, Devine KJ, Haydock PPJ, Jones PW (2007). Studies on the effect of mycorrhization of potato roots on the hatching activity of potato root leachate towards the potato cyst nematodes, Globodera pallida and G. rostochiensis. Nematology 9: 719-729.

Douds Jr DD, Nagahashi G, Pfeffer PE, Kayser WM, Reider C (2005). On-farm production and utilization of arbuscular mycorrhizal fungus inoculum. Can. J. Plant Sci. 85: 15-21.

Douds Jr DD, Nagahashi G, Reider C, Hepperly PR (2007). Inoculation with arbuscular mycorrhizal fungi increases the yield of potatoes in a high P soil. Biol. Agric. Hortic. 25: 67-78.

Drissner D, Kunze G, Callewaert N, Gehrig P, Tamasloukht M, Boller T, Felix G, Amrhein N, Bucher M (2007). Lyso-phosphatidylcholine is a 
signal in the arbuscular mycorrhizal symbiosis. Science 318: 265268.

Duffy EM, Cassells AC (2000). The effect of inoculation of potato (Solanum tuberosum L.) microplants with arbuscular mycorrhizal fungi on tuber yield and tuber size distribution. Appl. Soil Ecol. 15: 137-144.

Edwards SG, Young JPW, Fitter AH (1998). Interactions between Pseudomonas fluorescens biocontrol agents and Glomus mosseae, an arbuscular mycorrhizal fungus, within the rhizosphere. FEMS. Microbiol. Lett. 166: 297-303.

Elmer WH (2002). Influence of formononetin and $\mathrm{NaCl}$ on mycorrhizal colonization and Fusarium crown and root rot of asparagus. Plant Dis. 86: 1318-1324.

Farmer MJ, Li X, Feng G, Zhao B, Chatagnier O, Gianinazzi S, Gianinazzi-Pearson V, van Tuinen D (2007). Molecular monitoring of field-inoculated AMF to evaluate persistence in sweet potato crops in China. Appl. Soil Ecol. 35: 599-609.

Finckh MR, Schulte-Geldermann E, Bruns C (2006). Challenges to organic potato farming: Disease and nutrient management. Potato Res. 49: 27-42.

Frey-Klett P, Garbaye J, Tarkka M (2007). The mycorrhiza helper bacteria revisited. New Phytol. 176: 22-36.

Gadkar V, David-schwartz R, Kunik T, Kapulnik Y (2001). Arbuscular mycorrhizal fungal colonization. Factors involved in host recognition. Plant Physiol. 127: 1493-1499.

Gange AC, Bower E, Brown VK (2002). Differential effects of insect herbivory on arbuscular mycorrhizal colonization. Oecologia 131: 103-112.

Gaur A, Adholeya A (2000) Effects of the particle size of soil-less substrates upon AM fungus inoculum production. Mycorrhiza 10: 4348.

Gianinazzi S, Vosátka M (2004). Inoculum of arbuscular mycorrhizal fungi for production systems: Science meets business. Can. J. Bot. 82: 1264-1271.

Gosling P, Hodge A, Goodlass G, Bending GD (2006). Arbuscular mycorrhizal fungi and organic farming. Agric. Ecosyst. Environ. 113: 17-35.

Graham SO, Green NE, Hendrix JW (1976). The influence of vesiculararbuscular mycorrhizae on growth and tuberization of potatoes. Mycologia 68: 925-929.

Gyaneshwar P, Naresh Kumar G, Parekh LJ, Poole PS (2002). Role of soil microorganisms in improving $P$ nutrition of plants. Plant Soil 245: 83-93.

Hameeda B, Rupela OP, Wani SP, Reddy G (2006). Growth promotion of maize by phosphate solubilizing bacteria isolated from composts and macrofauna. Microbiol. Res. 163: 234-242.

Han HS, Supanjani, Lee KD (2006). Effect of co-inoculation with phosphate and potassium solubilizing bacteria on mineral uptake and growth of pepper and cucumber. Plant. Soil Environ. 52: 130-136.

Harrier LA, Watson CA (2004). The potential role of arbuscular mycorrhizal (AM) fungi in the bioprotection of plants against soilborne pathogens in organic and/or other sustainable farming systems. Pest Manage. Sci. 60: 149-157.

Harrison MJ (2005). Signaling in the arbuscular mycorrhizal symbiosis. Annu Rev. Microbiol. 59: 19-42.

Hol WHG, Cook R (2005). An overview of arbuscular mycorrhizal funginematode interactions. Basic Appl. Ecol. 6: 489-503.

Jeffries P, Gianinazzi S, Perotto S, Turnau K, Barea JM (2003). The contribution of arbuscular mycorrhizal fungi in sustainable maintenance of plant health and soil fertility. Biol. Fertil. Soils 37: 116.

Johansson JF, Paul LR, Finlay RD (2004). Microbial interactions in the mycorrhizosphere and their significance for sustainable agriculture. FEMS Microbiol. Ecol. 48: 1-13.

Karandashov V, Nagy R, Wegmüller S, Amrhein N, Bucher M (2004). Evolutionary conservation of a phosphate transporter in the arbuscular mycorrhizal symbiosis. Proc. Natl. Acad. Sci. USA 101: 6285-6290.

Khalid A, Arshad M, Zahir ZA (2004). Screening plant growth-promoting rhizobacteria for improving growth and yield of wheat. J. Appl. Microbiol. 96: 473-480.

Klironomos JN (2003). Variation in plant response to native and exotic arbuscular mycorrhizal fungi. Ecology 84: 2292-2301.

Klironomos JN, Hart MM (2002). Colonization of roots by arbuscular mycorrhizal fungi using different sources of inoculum. Mycorrhiza 12: 181-184.

Klironomos JN, McCune J, Hart M, Neville J (2000). The influence of arbuscular mycorrhizae on the relationship between plant diversity and productivity. Ecol. Lett. 3: 137-141.

Koide RT, Landherr LL, Besmer YL, Detweiler JM, Holcomb EJ (1999). Strategies for mycorrhizal inoculation of six annual bedding plant species. HortScience 34: 1217-1220.

Lang NS, Stevens RG, Thornton RE, Pan WL, Victory S (1999). Nutrient Management Guide: Central Washington Irrigated Potatoes. In (Wash. State Univ. Coop. Ext. 17.).

Larkin RP (2008). Relative effects of biological amendments and crop rotations on soil microbial communities and soilborne diseases of potato. Soil Biol. Biochem. 40: 1341-1351.

Lotter DW (2003). Organic agriculture. J. Sustainable Agric. 21: 59-128.

MacKay DC, Carefoot JM, Entz T (1988). Detection and correction of midseason $\mathrm{P}$ deficiency in irrigated potatoes. Can. J. Bot. Sci. 68: 523-534.

Maherali H, Klironomos JN (2007). Influence of phylogeny on fungal community assembly and ecosystem functioning. Science 316: 17461748.

Mamatha G, Bagyaraj DJ, Jaganath S (2002). Inoculation of fieldestablished mulberry and papaya with arbuscular mycorrhizal fungi and a mycorrhiza helper bacterium. Mycorrhiza 12: 313-316.

Marvázquez M, César S, Azcón R, Barea JM (2000). Interactions between arbuscular mycorrhizal fungi and other microbial inoculants (Azospirillum, Pseudomonas, Trichoderma) and their effects on microbial population and enzyme activities in the rhizosphere of maize plants. Appl. Soil Ecol. 15: 261-272.

McArthur DAJ, Knowles NR (1992). Resistance responses of potato to vesicular-arbuscular mycorrhizal fungi under varying abiotic phosphorus levels. Plant Physiol. 100: 341-351.

McArthur DAJ, Knowles NR (1993). Influence of species of vesiculararbuscular mycorrhizal fungi and phosphorus nutrition on growth, development, and mineral nutrition of potato (Solanum tuberosum L.) Plant Physiol. 102: 771-782.

Mishra N, Mohan A, Mishra US (2007). Effect of bio-fertilizers on biochemical and macronutrients of barley seeds. Biosci. Biotechnol. Res. 4: 285-288.

Niemira BA, Hammerschmidt R, Safir GR (1996). Postharvest suppression of potato dry rot (Fusarium sambucinum) in prenuclear minitubers by arbuscular mycorrhizal fungal inoculum. Am. Potato J. 73: 509-515.

Niemira BA, Safir GR, Hammerschmidt R, Bird GW (1995). Production of prenuclear minitubers of potato with peat-based arbuscular mycorrhizal fungal inoculum. Agron. J. 87: 942-946.

Plenchette C, Clermont-Dauphin C, Meynard JM, Fortin JA (2005). Managing arbuscular mycorrhizal fungi in cropping systems. Can. J. Plant Sci. 85: 31-40.

Potty V (1990). Use of lignite slurry as inoculating medium for vesicular arbuscular mycorrhiza in chinese potato (Coleus parviflorus). Plant Soil 125: 146-148.

Rausch C, Daram P, Brunner S, Jansa J, Laloi M, Leggewie G, Amrhein N, Bucher M (2001). A phosphate transporter expressed in arbusculecontaining cells in potato. Nature 414: 462-466.

Reddy SR, Pindi PK, Reddy SM (2005). Molecular methods for research on arbuscular mycorrhizal fungi in India: Problems and prospects. Curr. Sci. 89: 1699-1709.

Requena N, Serrano E, Ocón A, Breuninger M (2007). Plant signals and fungal perception during arbuscular mycorrhiza establishment. Phytochemistry 68: 33-40.

Rillig MC, Mummey DL (2006). Mycorrhizas and soil structure. New Phytol. 171: 41-53.

Ryan NA, Duffy EM, Cassells AC, Jones PW (2000). The effect of mycorrhizal fungi on the hatch of potato cyst nematodes. Appl. Soil Ecol. 15: 233-240.

Sanders FE, Tinker PB (1971). Mechanism of absorption of phosphate from soil by endogone mycorrhizas. Nature 233: 278-279.

Sessitsch A, Reiter B, Berg G (2004). Endophytic bacterial communities of field-grown potato plants and their plant-growth-promoting and 
antagonistic abilities. Can. J. Microbiol. 50: 239-249.

Shah SK, Shah RP, Xu HL, Aryal UK (2007). Biofertilizers: An alternative source of nutrients for sustainable production of tree crops. J. Sustain. Agric. 29: 85-95.

Smith SE, Read DJ(2008). Mycorrhizal symbiosis (Harcourt Brace, San Diego).

Steinkellner S, Lendzemo V, Langer I, Schweiger P, Khaosaad T, Toussaint JP, Vierheilig H (2007). Flavonoids and strigolactones in root exudates as signals in symbiotic and pathogenic plant-fungus interactions. Molecules 12: 1290-1306.

Straker CJ, Hilditch AJ, Rey MEC (2010). Arbuscular mycorrhizal fungi associated with cassava (Manihot esculenta Crantz) in South Africa. S. Afr. J. Bot. 76: 102-111.

Struik PC (2010). Can Physiology help us to combat late blight? Potato Res. 53: 277-287.

Tarbell TJ, Koske RE (2007). Evaluation of commercial arbuscular mycorrhizal inocula in a sand/peat medium. Mycorrhiza 18: 51-56.

van der Heijden MGA, Klironomos JN, Ursic M, Moutoglis P, StreitwolfEngel R, Boller T, Wiemken A, Sanders IR (1998). Mycorrhizal fungal diversity determines plant biodiversity, ecosystem variability and productivity. Nature 396: 69-72.

Van Overbeek L, Van Elsas JD (2008). Effects of plant genotype and growth stage on the structure of bacterial communities associated with potato (Solanum tuberosum L.). FEMS Microbiol. Ecol. 64: 283296.

Voets L, De Boulois HD, Renard L, Strullu DG, Declerck S (2005). Development of an autotrophic culture system for the in vitro mycorrhization of potato plantlets. FEMS Microbiol. Lett. 248: 111118.

Vosátka M, Gryndler M (1999). Treatment with culture fractions from Pseudomonas putida modifies the development of Glomus fistulosum mycorrhiza and the response of potato and maize plants to inoculation. Appl. Soil Ecol. 11: 245-251.

Vosátka M, Gryndler M (2000). Response of micropropagated potatoes transplanted to peat media to post-vitro inoculation with arbuscular mycorrhizal fungi and soil bacteria. Appl. Soil Ecol. 15: 145-152.
Wani PA, Khan MS, Zaidi A (2007). co-inoculation of nitrogen-fixing and phosphate-solubilizing bacteria to promote growth, yield and nutrient uptake in chickpea. Acta. Angron. Hung. 55: 315-323.

Whipps JM (2004). Prospects and limitations for mycorrhizas in biocontrol of root pathogens. Can. J. Bot. 82: 1198-1227.

Whitley KM, Davenport JR (2003). Nitrate leaching potential under variable and uniform nitrogen fertilizer management in irrigated potato systems. HortTechnology 13: 605-609.

Wu FS, Dong MX, Liu YJ, Ma XJ, An LZ, Peter W.J. Young, Feng HY (2011). Effects of long-term fertilization on AM fungal community structure and Glomalin-related soil protein in the Loess Plateau of China. Plant Soil 342: 233-247.

Wu SC, Cao ZH, Li ZG, Cheung KC, Wong MH (2005). Effects of biofertilizer containing $\mathrm{N}$-fixer, $\mathrm{P}$ and $\mathrm{K}$ solubilizers and $\mathrm{AM}$ fungi on maize growth: A greenhouse trial. Geoderma 125: 155-166.

Yao MK, Tweddell RJ, Désilets H (2002). Effect of two vesiculararbuscular mycorrhizal fungi on the growth of micropropagated potato plantlets and on the extent of disease caused by Rhizoctonia solani. Mycorrhiza 12: 235-242. 